\title{
Short Communication: Digenea parasites in giant mudskipper (Periopthalmodon schlosseri) in Kuala Lupak Village, South Kalimantan, Indonesia
}

\author{
HIDAYATURRAHMAH ${ }^{\vee}$, HERI BUDI SANTOSO ${ }^{\nu \vee}$, DESY NURAPRIANA ${ }^{\nu \vee \nu, ~ B A D R U Z S A U F A R I, ~}$ \\ MUHAMAT \\ Department of Biology, Faculty of Mathematics and Natural Sciences, Universitas Lambung Mangkurat. J1. A. Yani Km. 36 Banjarbaru 70714, South \\ Kalimantan, Indonesia. Tel./fax.: +62-511-4773112.`email: rahmahidayahipb09@yahoo.com, vvheri_budisantoso@yahoo.com, \\ •vdesy.gbio14@gmail.com
}

Manuscript received: 3 August 2019. Revision accepted: 28 November 2019.

\begin{abstract}
Hidayaturrahmah, Santoso HB, Nurapriana D, Badruzsaufari, Muhamat. 2019. Short Communication: Digenea parasites in giant mudskipper (Periopthalmodon schlosseri) in Kuala Lupak Village, South Kalimantan, Indonesia. Biodiversitas 20: $3782-3787$. Parasites are organisms that impart detrimental effects on their host. Monogenea which are generally ectoparasites and digenea which are endoparasites are the most common parasites which invade fish. This research was aimed to find out the existence of monogenean and digenean parasites as well as their species in giant mudskipper or timpakul fish (Periopthalmodon schlosseri) in Kuala Lupak Village, South Kalimantan, Indonesia. Employing 25 giant mudskipper which was randomly collected from Kuala Lupak Village, South Kalimantan, this study explored the presence of ectoparasites and endoparasites on the mucous, fins, gills, intestines, stomach, and meat of the fish. The results showed that only digenean parasites were found in the giant mudskipper (Periopthalmodon schlosseri). The digenean parasites found to come from Opecoeloides genus and Buchepalidae family, metacercariae cysts, and parasites of the nematode phylum. Monogenea parasites were not found due to low fish-density, fish behavior that is rarely in the water, and adequate nutrition which is the opposite of growth-supporting factors of monogenean. Parasitic infection could occur because the fish eat some intermediate hosts of digenea, such as snails and other fish. Besides, the condition of waters that have been contaminated with digenean eggs allows the life cycle of the digenean to continue in fish.
\end{abstract}

Keywords: Bucephalidae, descriptive, Opecoeloides, parasites, Periopthalmodon schlosseri

\section{INTRODUCTION}

Parasites are organisms that can adapt and harm the organisms they occupy (Sutisna and Sutarmanto 1995). In fish, the parasites are divided into two types, according to the area in which they invade: ectoparasites and endoparasites. Parasites, both endoparasites, and ectoparasites, can cause tremendous negative effects which are very detrimental to their host. Endoparasites can generate swelling or deflation in the fish stomach. They can even cause the inflammation of the intestines (Rahmaningsih 2016). In addition, endoparasites can also attack swimming bubbles resulting in the loss of fish balance when swimming. On the other hand, ectoparasites usually invade the skin and gills. When this happens, the fish skin will look paler and slimmer. On the gills, ectoparasite can make the fish have some difficulties in breathing, characterized by the expansion of the gill cover which makes it paler in color. Red spots on the gill sheets are also caused by minor bleeding as the result of ectoparasite infection (Afrianto and Liviawaty 1992).

Giant mudskipper or timpakul fish (Periopthalmodon schlosseri) - or often called gelodok fish - belong to the family of Gobiidae which have amphibian-like lifestyle. Giant mudskipper hunt for food and are active when the water recedes. This makes the fish different from most fish (Nugroho et al. 2016). Giant mudskipper is found thriving in habitats that have been converted into fish ponds since fish, crabs, shrimps, and frogs which are the main meal for the giant mudskipper exist in such area (Hidayaturrahmah and Muhamat 2013). Based on Muhamat et al. (2017), shrimps and crabs are animals that have the potential to become the food for giant mudskipper. Unfortunately, shrimps and crabs cannot be separated from parasitic infections, in which they are generally infected by ectoparasites. This situation underlines the fact that the giant mudskipper can also be infected by parasites coming from their food sources which have been infected with parasites before.

In Bray and Justin (2013) study, Periophthalmus argentilineatus -one of the giant mudskipper species which lives in the New Caledonia mangrove forest- is found to be infected by parasites. These fish are infected by digenea with a prevalence of $93 \%$ in the intestine, Achantocephala larvae with a prevalence of $47 \%$ in the abdominal cavity, and nematodes with the prevalence of $13 \%$ on the surface of the liver. In addition, Polgar et al. (2009) also state that leeches are one of the parasites which can be classified into ectoparasites attacking the giant mudskipper.

In some parts of the world, for example in the coastal areas of Nigeria, giant mudskipper is widely consumed as a food source because these fish are cheap and widely available for most of the year (Edun et al. 2010). In addition, they have potential in the world of health as 
traditional medicine. Unfortunately, if the fish are not processed properly, they may affect human health as the consumers; due to the fact that some fish may possibly be infected by various parasites. Thus, it is necessary to conduct the effort for early prevention by identifying the parasites existing in the fish to reduce the risk and loss to fish and humans who consume them.

In Kuala Lupak Village, Latrines or toilets are found along with the river flow in which these disposals discharge their waste directly to the river. This allows the digenean eggs to be released directly by definitive hosts such as fish, birds, and mammals, but in this case, humans who directly dispose of the feces into the river. Information regarding monogenean and digenean parasites in giant mudskipper, especially in Kuala Lupak Village, Kuala, South Kalimantan, has not been found because there has never been a study previously. On the other hand, the giant mudskipper population is very abundant and easily found. Based on the problems above, this research is expected to generate information for further research in terms of the use of giant mudskipper as food and health products.

\section{MATERIALS AND METHODS}

\section{Sample collection}

Twenty-five mudskippers (Periopthalmodon schlosseri) were taken randomly as samples from Kuala Lupak Village, Tabunganen Subdistrict, Barito Kuala District, South Kalimantan, Indonesia.

\section{Sample examination}

Fish samples that were examined were previously terminated. Then, their weight $(\mathrm{g})$ and length $(\mathrm{cm})$ were measured (Maulana et al. 2016). The examination was carried out on the outside and inside parts of the fish body, namely the body surface, fins, gills, mucus, stomach, intestine, and meat.

\section{Ectoparasite examination}

After the surface of the fish body was observed, the mucus on the surface of the fish body was scraped off using a scalpel, and a review was made on the object-glass in which aquadest exists. Furthermore, fish fins were cut and placed on object-glass with aquadest. Next, all fish gills were also taken and placed on glass objects with aquadest. Finally, all samples were observed under a microscope (Hadiroseyani et al. 2006).

\section{Endoparasite examination}

The fish belly was opened by cutting the lower abdomen from the anus to the pectoral fin. The cover of the abdominal cavity was opened and cut along the gill cover, so that the contents of the stomach are visible. The stomach contents (viscera) were transferred to petri dishes which contained physiological $\mathrm{NaCl}$. The parts of the intestine and stomach which were sliced and extracted by scraping using a spatula were then placed on the glass object. Meanwhile, the meat was firstly observed macroscopically; and if there were worms, the meat would be observed microscopically (Maulana et al. 2016).

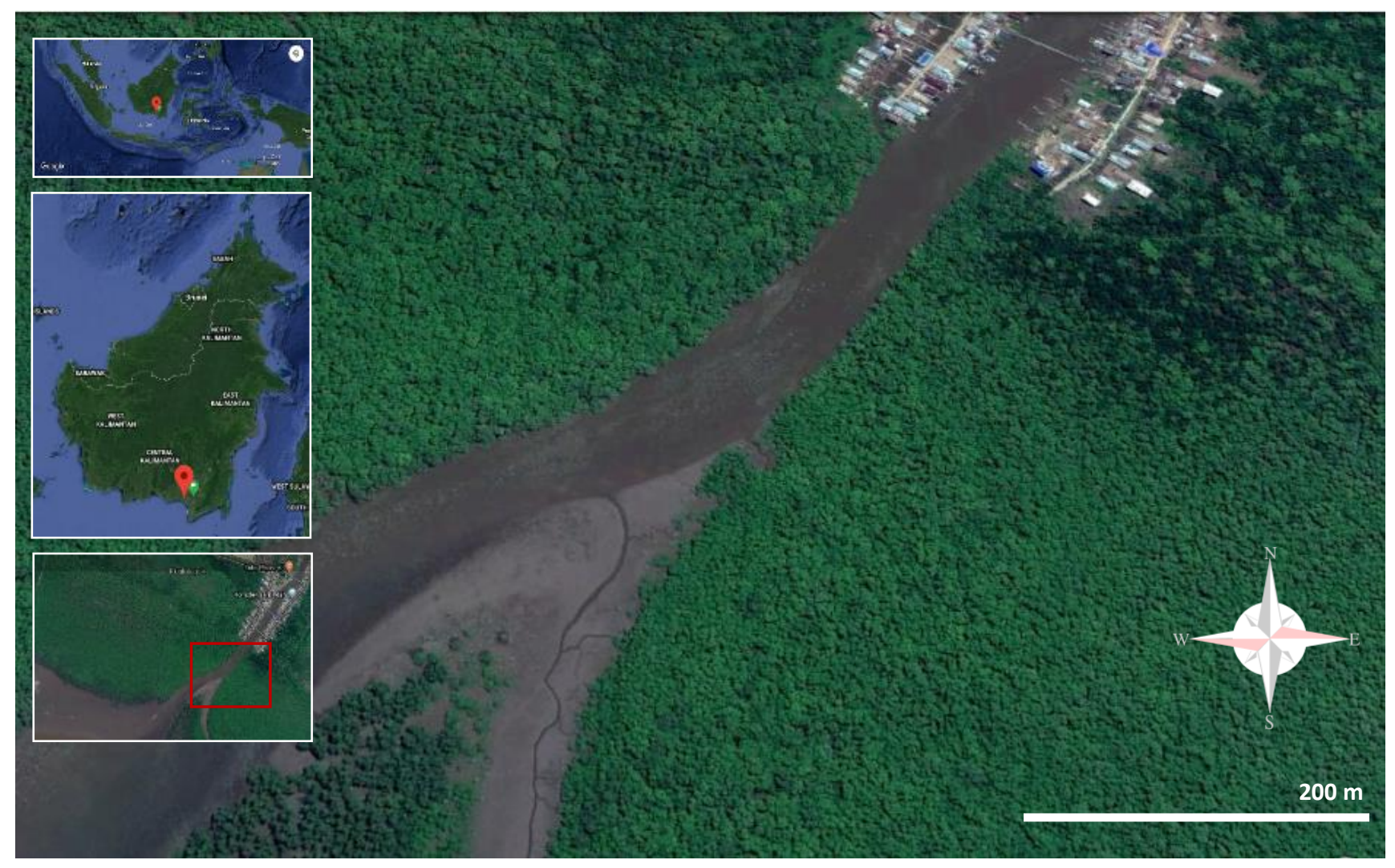

Figure 1. Location of sample collection of Periopthalmodon schlosseri in Kuala Lupak Village, Tabunganen Subdistrict, Barito Kuala District, South Kalimantan Province, Indonesia 


\section{Endoparasite examination}

The fish belly was opened by cutting the lower abdomen from the anus to the pectoral fin. The cover of the abdominal cavity was opened and cut along the gill cover, so that the contents of the stomach are visible. The stomach contents (viscera) were transferred to petri dishes which contained physiological $\mathrm{NaCl}$. The parts of the intestine and stomach which were sliced and extracted by scraping using a spatula were then placed on the glass object. Meanwhile, the meat was firstly observed macroscopically; and if there were worms, the meat would be observed microscopically (Maulana et al. 2016).

\section{Observation and identification}

Samples that had been diluted with physiological $\mathrm{NaCl}$ were partially dropped onto the glass object. The parasites found were then preserved by fixation with $10 \%$ formalin for 5-10 minutes. Then, they were hydrated with $70 \%$ alcohol, and cleared using xylol. The preparations were completed with entellan, so that it was ready for the observation (Nofyan et al. 2015). Observations were conducted by using a microscope with small to large magnifications and documented with a digital camera. The identification of monogenean parasites refers to Margolis and Kabata (1984) while the identification of digenean parasites refers to Margolis and Kabata (1996).

\section{Data analysis}

The data obtained from the results of parasites identification of giant mudskipper (Periopthalmodon schlosseri) were analyzed descriptively.

\section{RESULTS AND DISCUSSION}

Fish examined are 25 giant mudskippers (Periopthalmodon schlosseri). The fish samples were collected randomly from Kuala Lupak Village, Tabunganen Subdistrict, Barito Kuala District, South Kalimantan Province. Indonesia. Digenea parasites that infect the fish come from Opecoeloides genus and Bucephalidae family. In some fish, only metacercariae digenea was found in fish fins and gills, while 4 fish were not infected by the parasites.

The parasites found were then observed under a microscope, so that they could be identified. The parasites found were directly observed to see the morphology of the body parts, and to make the preserve. Digenea is a parasite that is very easy to shrink if preserved, so that not all preserves were made to generate good results. Not all digenean parasites could be identified up to the level of genus or species, because the condition of body organs as a reference for identification was not all clearly visible. Thus, digenea could only be identified to the level of family and genus. Digenea found were not only adult digenea but also that which were still in the metacercariae stage. The metacercariae found cannot be identified based on their type because their shapes were still unclear, and their organs were still not fully formed. In addition to digenean parasites, other parasites were also found. These parasites were nematodes with elliptical (gilik) characteristics or similar to threads, cylindrical or elliptical body shapes which are not segmented, and increasingly toward the posterior forming a tapered tip.

\section{Opecoeloides genus}

The classification of this parasite is Animalia kingdom, Platyhelminthes phylum, Trematoda class, Digenea subclass, Plagiorchiida order, Paramphistomoidea superfamily, Opecoelidae family and Opecoeloides genus (Margolis and Kabata 1996). The worms found in giant mudskipper are adult worms from the intestines and stomach of the fish. Opecoloides has a body that is elongated, smooth, and rounded at both ends of the body; however, when it moves, the posterior part is tapered, having a length of 0.76 to 1.02 $\mathrm{mm}$ and a width of 0.21 to $0.29 \mathrm{~mm}$. Its mouth is called oral sucker which is very close to the oval anterior and can shape a circle if it opens perfectly. The size of the open mouth ranges from 0.09 to $0.12 \mathrm{~mm}$ in diameter. The mouth is equipped with pharynx that looks like an oral sucker but is more likely to be oval in the size of 0.03 to $0.06 \mathrm{~mm}$. It also has a ventral sucker which is larger than the oral suckers with size ranging from 0.10 to $0.16 \mathrm{~mm}$ in diameter located in almost mid-body, semi-embedded, and equipped with papillae. On the other hand, accessory sucker is located almost parallel to the pharynx and is on the left. Besides those organs, there are some organs that belonged to the parasites. Cecum is a long, narrow, and open organ to the excretory vesicle, close to the end of the body. It forms an uroproct and is sac-shaped. Other organs such as genital pore, testicle, seminal vesicles, ovaries, and uterus are not clearly visible. The morphology of Opecoeloides can be seen in Figure 2.

\section{Family Bucephalidae \\ Bucephalidae}

The classification of this parasite is Animalia kingdom, Platyhelminthes phylum, Trematoda class, Digenea subclass, Strigeata order, Gymnophalloide superfamily, and Bucephalidae family (Margolis and Kabata 1996). The worms found in giant mudskipper are adult worms from the intestines and stomach of the fish. This parasite has a body that is elongated and extended in the middle of the body. The mouth is isolated and away from the anterior, with simple digestion, but without ventral suction. Bucepahalidae family has an elongated body. Bucephalidae has also an anterior organ that is present in the form of suction or rynchus as a characteristic. The rynchus is broad, relatively short, and blunt. Bucephalidae's mouth is far apart from the anterior organ. The excretory vesicles are tubular. The genital pore is located in the posterior region. The other organs of the body such as the ovaries, caeca, testicle, seminal vesicles, pars prostarica and eggs are not clearly visible. The morphology of Bucephalidae can be seen in Figure 3. 

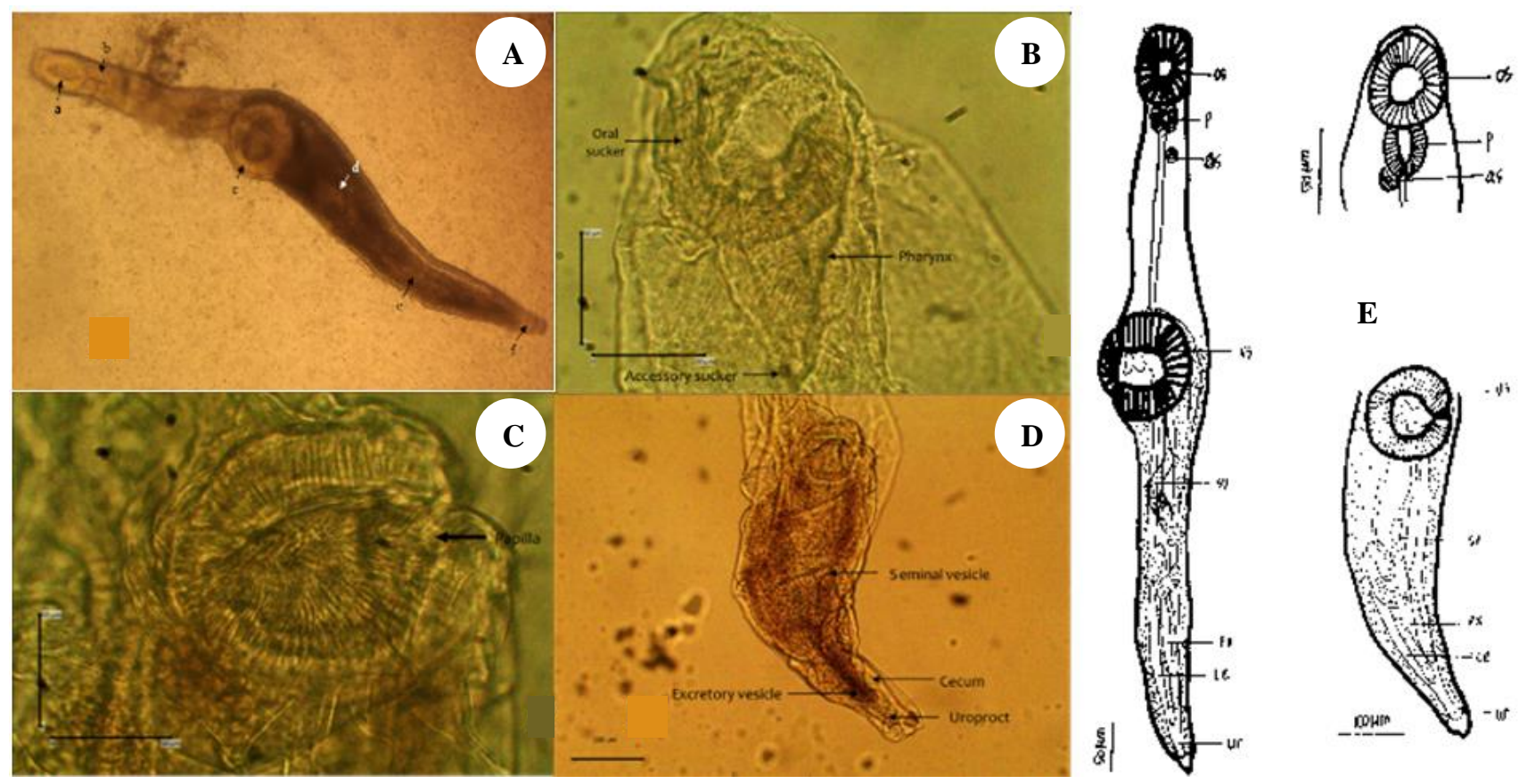

$\mathbf{E}$

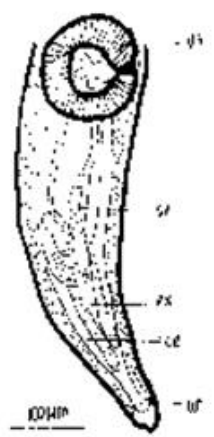

Figure 2. A. Opecoeloides; a. Oral sucker, b. Pharynx, c. Ventral Sucker/Acetabulum, d. Seminal Vesicle, e. Excretory vesicle, f. Uroproct, B. Anterior of Opecoeloides, C. Ventral sucker, D. Posterior of Opecoeloides, E. Morphology of Opecoeloides: Os (oral sucker); P (Pharynx); As (Accessory sucker); Vs (Ventral sucker); Sv (Seminal vesicle); Ex (Excretory vesicle); Ce (Cecum); Ur (Uroproct)
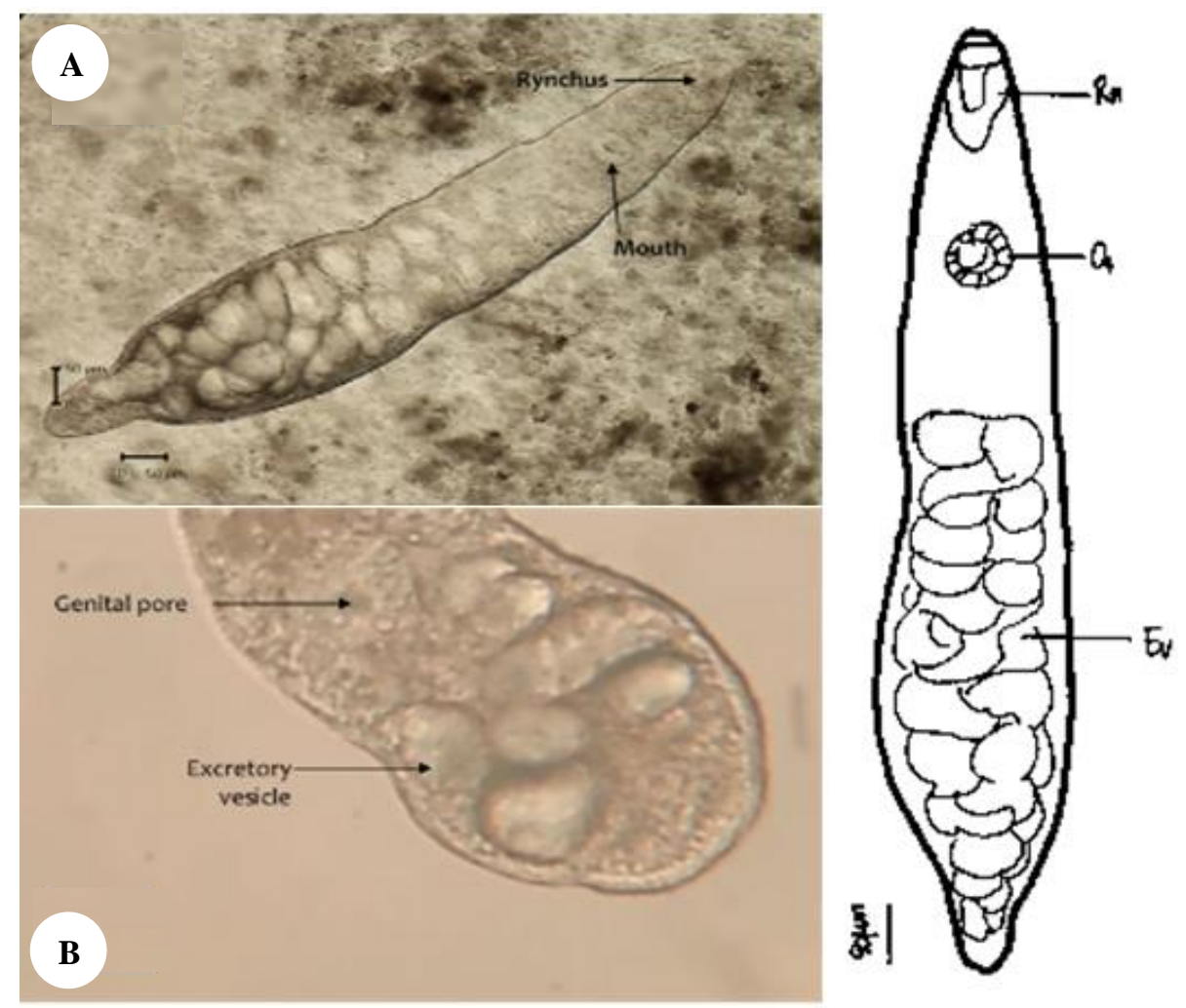

C

Figure 3. A. Bucephalidae, B. Posterior of Bucephalidae, C. Morphology of Bucephalidae: Rn (Rynchus); Os (Oral sucker); Ev (Excretory vesicle); Gp (Genital pore) 


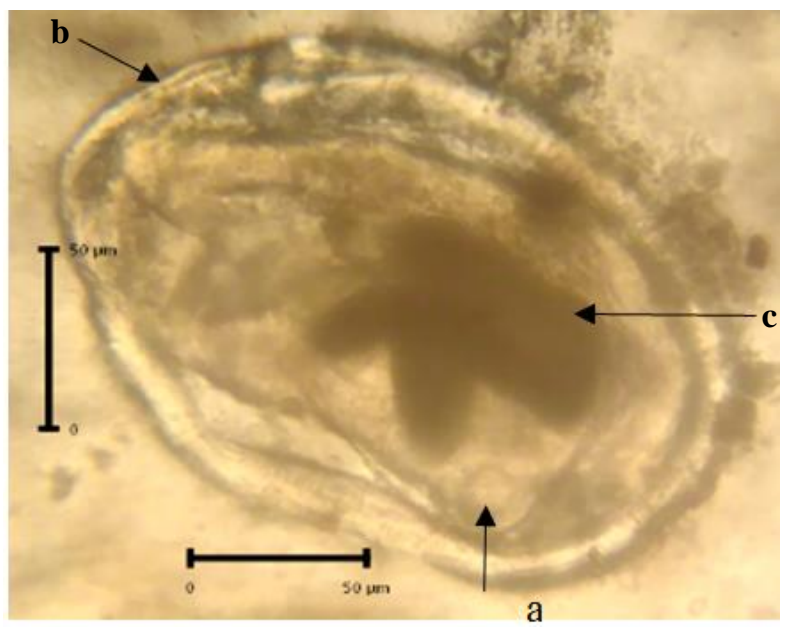

Figure 4. Metacercaria cyst: a. Ventral sucker; b. Wall of cyst: c. Excretory bladder

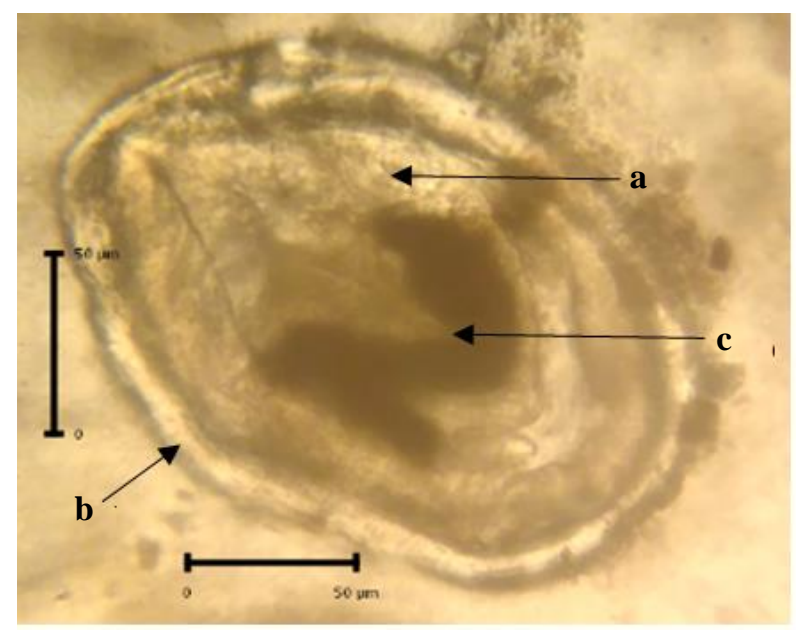

Figure 5. Metacercaria cyst: a. Oral sucker; b. Wall of cyst: c. Excretory bladder

\section{Metacercariae cyst}

The form of metacercariae found in the giant mudskipper in this study is similar to capsules with cysts that are still wrapping. The metacercariae are found in gills, scales, and fish fins with a size of 0.20 to $0.28 \mathrm{~mm}$. The metacercariae are covered by a thick cyst wall. There are parts of the body with a thicker brown color. The oral suckers and ventral suckers are clearly visible, where the eyespots are not visible. The cyst walls become thicker, and the oral and ventral suckers thicken. Brown pigments are still scattered in groups in body parts and excretory organs. As it becomes darker, the worms become more active (Figures 13 and 14). The metacercariae found on the fins (Figure 16) has a thin cyst wall and clear eyespot, characterizing metacercariae entering the age of 7 days. The metacercariae found in the gills show brown pigment groups on the lateral side of the body, with thicker cysts and suckers which can be seen clearly. The metacercariae with this character enter the age of 14 days. These characteristics are in accordance with the research of Kopolrat et al. (2016). The morphology of metacercariae can be seen in Figures 4 and 5.

\section{Discussion}

Based on the examination of the giant mudskipper, only four fish are free from parasitic infections. These fish are around 36 to $109 \mathrm{~g}$ in weight and 16 to $22.5 \mathrm{~cm}$ in length. These ranges of weight and length make the four fish as the smallest compared to the ranges of weight and length of other fish in the sample. The size of fish actually determines the age of the fish. The bigger the body size is, the older the age of the fish will be. Older fish have longer contact with parasites in the water, making them more susceptible to parasitic infection. In addition to age, larger fish will also affect the presence of parasites, since broader surface area of the body contributes to more opportunity for parasites to invade (Maulana et al. 2017). This is related to the fact that larger-sized and longer-sized giant mudskipper has been infected with parasites.

The distribution of parasites is inseparable from the food source and eating habits of the host, in this case, the giant mudskipper and the environmental conditions that contribute to the availability of abundant fish feed. The types of food consumed by the giant mudskipper depend on the species of giant mudskipper itself. One of their ways to eat is by taking mud using their mouth, so that it can collect algae after filtering the residue. The giant mudskipper can be either omnivorous or carnivorous. Omnivorous giant mudskipper eats small crustaceans and plants, while carnivorous giant mudskipper eats crabs, insects, snails, and some smaller giant mudskipper. The giant mudskipper can only be found in mangrove area because of its food availability that can meet their nutritional needs (Gosal et al. 2013). This is in line with the statement of Goulding et al. (2004) that the life cycle of the digenean parasites requires Mollusca; in this case, snails become the first intermediate host. The giant mudskipper eating snails which have been infected with miracidium will continue the life cycle of the digenean parasite in the body of the fish as the second intermediate host.

Previous research conducted by Mahardika (2017), concerning the eating behavior of giant mudskipper in Tanipah, the estuary of Barito River in South Kalimantan, explains that giant mudskipper eats crabs, insects, and other fish. It can be seen from their digestive contents. Based on the life cycle of digenean parasites described by Goulding et al. (2004), the digenean parasites have some ways to infect giant mudskipper: through consumed snails that have brought miracidium, through preying other fish which previously have digested cercaria, or through the giant mudskipper itself that swallow cercariae which was released into the water of by mollusks. 


\section{ACKNOWLEDGEMENTS}

The researcher would like to say thank you to the Ministry of Research and Higher Education of Indonesia (KEMRISTEKDIKTI) through the PDUPT RISTEKDIKTI SD DIPA-042.06-1.401516/2018 No. 40/UN8.2/PL/2018.

\section{REFERENCES}

Afrianto E, Liviawaty E. 1992. Pengendalian Hama dan Penyakit Ikan. Kanisius, Yogyakarta. [Indonesian]

Bray RA, Justine JL. 2013. A digenean parasite in a mudskipper: Opegaster ouemoensis sp. n. (Digenea: Opecoelidae) in Periopthalmus atgentilineatus Valenciennes (Perciformes: Gobiidae) in the mangroves of New Caledonia. Folia Parasitol 60 (1): 7-16.

Edun OM, Akinrotimi OA, Uka A, Owhonda KN. 2010. Patterns of mudskipper consumption in selected fishing communities of rivers state. J Agric Soc Res 10 (2): 100-108.

Gosal LM, Katili DY, Singkoh MFO, Tamanampo JEWS. 2013. The food habit of mudskipper fish, Periophthalmus sp. in mangrove areas of Meras Beach, Bunaken Subdistrict, Manado City, North Sulawesi. J Bios Logos 3 (2): 44-49. [Indonesian]

Goulding DR, Blankenship-Paris TL, Lewbart GA, Myers PH, Demianenko TK, Clark JA, Forsythe DB. 2004. Gill Trematodes (Flukes) in Wild-Caught Killifish (Fundulus heteroclitus). 43 (2): 32 34.

Hadiroseyani Y, Hariyadi P, Nuryati S. 2006. Inventarisasi parasit lele dumbo Clarias sp. di Daerah Bogor. J Akuakultur Indonesia 5 (2): 167-177. [Indonesian]

Hidayaturrahmah, Muhamat. 2013. Habitat ikan muskipper (Periopthalmodon schlosseri) di Muara Sungai Barito. Enviro Sci 9 134-139. [Indonesian]

Kopolrat K, Sithithaworn P, Kiatsopit N, Pitaksakulrat O, Tesana S, Andrews RH, Petney TN. 2016. Comparison of infectivity, metacercarial burden and host mortality induced by Opisthorchis viverrini Sensu lato Cercariae from Lao PDR compared with Thailand in Cyprinid fish, Barbonymus gonionotus. Trans R Soc Trop Hyg 110: 46-54.

Mahardika M. 2017. Perilaku Makan Ikan Timpakul (Periopthalmodon schlosseri) di Tanipah Muara Sungai Barito Kalimantan Selatan. [Hon. Thesis]. Pogram Studi S-1 Biologi, Fakultas Matematika dan Ilmu Pengetahuan Alam, Universitas Lambung Mangkurat, Banjarbaru.

Margolis L, Kabata Z. 1984. Guide to the Parasites of Fishes of Canada Part I. National Printers (Ottawa) Inc., Canada

Margolis L, Kabata Z. 1996. Guide to the Parasites of Fishes of Canada Part 4. NRC Research Press, Ottawa, Canada.

Maulana DM, Muchlisin ZA, Sugito S. 2017. Intensitas dan prevalensi pada ikan betok (Anabas testudineus) dan perairan umum daratan Aceh Bagian Utara. Jurnal Ilmiah Mahasiswa Kelautan dan Perikanan Unsyiah 2 (1): 1-11. [Indonesian]

Muhamat, Santoso HB, Hidayaturrahmah. 2017. Adaptasi ikan muskipper (Periopthalmodon schlosseri) di habitat terganggu Muara Sungai Barito, Kalimantan Selatan. Biospecies. 10 (2): 60-66. [Indonesian]

Nofyan E, Ridho MR, Fitri R. 2015. Identifikasi dan prevalensi ektoparasit dan endoparasit pada ikan nila (Oreochromis niloticus Linn) di kolam budidaya Palembang, Sumatera Selatan. Prosiding Semirata 2015 bidang MIPA BKS-PTN Barat Universitas Tanjungpura, Pontianak. [Indonesian]

Nugrono ED, Ibrahim, Rahayu DA, Rupa D. 2016. Studi morfologi ikan mudskippers (Gobiidae: Oxudercinae) sebagai upaya karakterisasi biodiversitas lokal Pulau Tarakan. J Harpodon Borneo 9 (1): 46-57. [Indonesian]

Polgar G, Burreson EM, Stefani F, Kamrani E. 2009. Leeches on mudskippers: Host-parasite interaction at the water's edge. J Parasitol 95 (4): 1021-1025.

Rahmaningsih S. 2016. Hama dan Penyakit Ikan. Deepublish, Yogyakarta. [Indonesian]

Sutisna DH, Sutarmanto R. 1995. Pembenihan Ikan Air Tawar. Kanisius, Yogyakarta. [Indonesian] 